\title{
The Construction of Life Education Curriculum System in Colleges
}

\author{
Yang Wang ${ }^{1, a}$ and Zhonghua Chen ${ }^{2, b}$ \\ ${ }^{1}$ Northeast Normal University, Changchun, 130117, China \\ ${ }^{2}$ Armor Technique Institute of PLA, Changchun, 130117, China \\ a294244476@qq.com, b165007605@qq.com
}

Keywords: Colleges; College students; Life education curriculum; Construction

\begin{abstract}
The university students' individual life stage is gradually mature, independent thinking, outlook on life, world outlook and values gradually formed, gradually entered a critical period of social. In this stage, the problem of college students will directly affect the development of life, not only can not promote their own life, and even hurt others and society. Curriculum is the most direct and effective means of education in Colleges and universities. At present, we must attach importance to the curriculum of life education for college students. This paper analyses problems of life education curriculum in Colleges and universities, and expounds the realistic basis of curriculum implementation and its importance, and the construction of university life education curriculum, the implementation process of the life education curriculum for the detailed interpretation.
\end{abstract}

\section{Introduction}

The university stage is the individual student life becoming independent, mature thought, outlook on life, world outlook and values gradually formed, gradually entered a critical period of social. Once the problem of college students in this stage, will directly affect the development of life, not only can not guarantee their own life, and even hurt others and society. At present, there are many problems in college students' life, which is closely related to the lack of life education. Therefore, we must attach importance to the life education of college students, and incorporate them into the main body of the university education system. The practice of life education lags behind the theoretical exploration. At the same time, it has been paid close attention to, and has been mentioned in the strategic position, which is also a new field. "Long term education reform and development plan in the country (2010 - 2020)" clearly put forward the "people-oriented, comprehensive implementation of quality education is the strategic theme of education reform and development, should pay attention to safety education, life education, national defense education, sustainable development." For the first time, "life education" is a major theme of national education. To carry out life education in Colleges and universities, we must focus on curriculum. At present, there is no independent life education curriculum in Chinese University campus, which should not be paid enough attention to.

\section{Problems Faced by Life Education Curriculum in Colleges}

The Role of Life Education Curriculum Is not Taken Seriously, Resulting in the Lack of Appropriate Ecological Orientation. The main course of life education is to help people understand and cherish his life, respect life, thinking about the meaning of life and on this basis, find the value and position of their own existence, enhance the quality of life, the cultivation of humanistic spirit. The status quo, some colleges and universities throughout the author found that, in the current university education, the education requirements of the education object put more focus on the knowledge and skills of memorization, individual life, spirit and soul of the degree of concern is not enough. Therefore, it is difficult to achieve the rational degree of education guidance.

The Lack of Dialogue Mechanism in the Life Education Curriculum Management, Leading to Disharmony of Community Relations. Education is the "human spirit", "spirit communication 
between the main person to person activities". Only through the dialogue between teachers and students to achieve the relevance of life, in order to achieve the care of life. But for a long time, because the teacher's life consciousness is weak, lack of ecological awareness, lead teachers and symbiotic paradigm, for the management of the disorder vicious spiral relationship provides a hotbed, potentially resulting in poor group mentality. Affected by this, the students in the development of their own space at the same time, intentionally or unintentionally to obstruct the development of other individuals in the same level niche. At the same time, the current students in all kinds of relationships, "the role of emotion and reason" gradually lost, showed the independent consciousness and "self-centered" consciousness, to deal with all kinds of relations exist more or less tension.

Life Education Curriculum in the Implementation of a Closed, Resulting in Ecosystem Disruption. At present, the phenomenon of the lack of life education curriculum for college students is stills less. In some of the colleges and universities that offer this course, it is often closed in practice, which leads to the disruption of ecosystem. From the ecological perspective, the life education curriculum closed similar to the flowerpot effect (flower pot effect) is also known as the local habitat effect, which is 1.5 small pots and semi artificial natural ecological environment, in the space is limited, but also to create a suitable environment for. In the flowerpot, the individual and the group will lose their viability if they leave this small ecological environment. This requires that life education courses should adhere to the principle of openness, actively integrate into society, to avoid the greenhouse effect".

\section{The Construction of Life Education Curriculum in Colleges}

Guiding Curriculum Concept. Life is a structure with multiple layers and dimensions of the body, is a contradictory relationship perplexing body, there is a special value by a variety of factors interwoven, and knowledge is not the inevitable positive correlation. Therefore, life education curriculum is not only related to the structure of knowledge, but also the relationship between knowledge and life". In another sense, life education curriculum is not only a course, but also a "people-oriented" value ideal and educational philosophy. As Beijing Normal University Professor Xiao Chuan believes, "life education is not only an educational practice, but also the value of education". "Life" needs a kind of "care for life" education, the value of life as the scale and direction, focusing on the connotation and extension of life.

Clear Course Objectives. Jaspers's holistic thinking is of great significance for the cultivation of the whole life of College Students' life education, and the guidance of the university education to the exploration of the inner basis of "people" and the gradual development of "life". Life is a complete and unified relationship, including the life self existence, social existence, life, life value and life rights life-power five themes, each plays a different role and function. If you leave any of these elements, the life is incomplete. The curriculum of life education for college students from the ontology cognition of life as a starting point, to give attention to ontology of life, and strive to break through the traditional framework of "special cognitive theory", the transformation from "cognitive" to "life complete".

Diversity of Curriculum. The construction of life education curriculum needs to solve the basic form of curriculum, which is the form and type of curriculum and curriculum. This paper argues that the life education of college students can take a variety of types of courses, the following four basic courses: specialized courses, integrated curriculum, hidden curriculum, activity curriculum. The curriculum of life education curriculum is dynamic, internal and external balance is a dynamic balance, maintaining the balance not only maintain the stability of the original, but also through the course of interaction with the environment, to establish a new balance, to achieve a more reasonable structure, more effective play function and get better results. Activity curriculum is a necessary supplement. We can take the form of lecture, discussion and value clarification, strengthen dialogue and communication, and achieve the correct understanding and Reflection on life.

Compatibility of Course Content. To show the curriculum content of life theme system. The different needs of society, the development of individual factors, changes in the social environment 
will affect the choice and restrict the course of College Students' life education content, so life education curriculum content is different in different. However, the design of the course content should include at least five themes: the existence of life, the existence of life society, the value of life, the power of life and the right to life. Right face impermanence phenomenon in life; the courage to face the frustration and suffering all kinds of interpersonal relationships; to understand the principle of understanding; the importance of family, national importance; respect the universal order of life; establish the life of goodness value pursuit; good at finding the implementation path of teaching and explore the role of life.

Taking into account the content of science and humanity. In the course content, the life education is not only the education of the natural science, but also the education of the humanities meaning. Natural science education major is to explore the regularity of natural life science rationality; direction and explore humanistic significance of education focuses on the humanistic significance of spiritual life, to the meaning of life. The so-called human meaning of education is to construct the whole life cognition, knowledge from the center to the center of life, from the theoretical teaching to experience perception, from the external to the internal planning introspection, the basic value orientation of the experience curriculum, taking into account the world of life and science, care knowledge generation and life practice, reflecting the organic unity of Humanities and science the spirit, highlighting the course in life, take care of in the course of life.

Open Curriculum Implementation. The moment of life is in the dynamic evolution, and the moment of the ecological system of dynamic symbiosis. Life education is not limited to a certain course, a classroom teaching, it is also the field whenever and wherever possible, the evolution of growth time. The implementation of life education curriculum can jump out of subjects, time is limited, to infiltrate the various teaching activities, and even extends to the school life, students' life flow. "Rather than discuss action, practice is the field of basic life, but also a carrier of life development. The growth of individual life is created in the practice of relationship, continuous and dynamic integration. Practical activity is the natural extension and beneficial supplement of life education class. The living world is the realistic foundation and the source of the meaning of the education world. Practice makes it possible to return to the life world.

Effectiveness of Curriculum Evaluation. Life education curriculum should actively create a mode of operation that takes into account the interests of all parties. For the evaluation of the curriculum, students, teachers, parents, community members are given the right to speak. First of all, the course of College Students' life education to guide students to pursue the "consciousness and the ability to reflect and try to find the cause. The purpose of pursuing life, the reflection on the plight of the existence of life, an individual heart confused. Students' subject participation and life cognition are the focus of curriculum evaluation. Secondly, the teacher of life experience to awaken the consciousness of the main body, students' self evaluation, self correction, conservation and rational knowledge to improve students' thinking ability. The teacher's demonstration and observation is the supporting point of curriculum evaluation. Finally, the family and the community are the dynamic environmental factors of curriculum implementation, and have a variety of influence on the life education curriculum. College students are finally going to the society, the real life. Tolerance and timely supervision of parents and social groups is the end result of curriculum evaluation.

\section{The Implementation of Life Education Curriculum in Colleges}

To Clarify the Role of Life Curriculum and to Give Appropriate Niche. The education system in the large ecological chain on the establishment of the life education curriculum "niche", is to give the life education of science and rationality; the independent and formal curriculum status; the integration, continuity, continuous cultivation; reasonable definition of course, guarantee the effective implementation of the course of time. Of course, the independent life education curriculum should also establish a united front with the integration curriculum, activity curriculum and hidden curriculum". In the current course in organic integration and ingenious penetration of life education content, embodied cognition and perception of life in comprehensive activities, create life 
atmosphere in the campus environment, and an important supplement to the beneficial attempt in the process of implementation of the life education curriculum is independent.

Equipped With Good Teachers to Form a Dialogue Mechanism. The meaning of life education curriculum is not a separate presentation or transmission, but through the open thinking, narrative regulation, revised interpretation and emotional perspective, open dialogue and communication between teachers and students. Teachers should change the role of knowledge transfer station, in the process of imparting knowledge into the life experience of the heart and mind and student exchanges. With the life to education, strong call "life to warm life, with the life to protect life, with the life to hit life, with life to brilliant life". Teachers should learn to carry on the equal dialogue with the students, through the dialogue to dispel authority, then guide the equal dialogue between the students, and promote the formation of the interactive mechanism. Teachers should be based on student life, respect for the subjectivity of students' life, cultivate students' subjective consciousness. In the course of life education teaching, teaching design according to different characteristics, as life close to the needs of the students, so as to arouse their sympathy and help them solve practical problems in life, cause the student to love and life in the sense of responsibility and knowledge.

Innovative Teaching Methods to Promote the Development of Curriculum. Teaching experience is the teachers and students through teaching interaction and role exists as a kind of life activity and course in the teaching, teachers and students will be all in the mind into it, through the self life, and the lives of others and interaction of the natural world fusion know life, life experience, life development. So, teaching experience is not only a pure cognitive activity, a rigid rigid teaching paradigm or pattern, it is more a kind of educational idea and form, is the meaning of life, creation and coagulation process is a process of presentation and life force, is the main experience for life the connotation and transcendence, significance and value with the methodology. Life narration method is mainly by means of scene, emotion, rhythm and other non logical thinking, with the unique structure of the story and vivid content to express their own life existence, life practice and life experience, with the exchange of information, interactive process to achieve educational function between the narrative subject and audience. In the course of life education for college students, teachers as long as the good design situation, choose life narrative narrative of life case, capture life narrative theme and outstanding life narrative expression, will be able to tap the students' life experience, share of students' life emotion, sublimation of students life will improve students' comprehension ability, judgment ability and life practice ability.

Build a Good Support Platform to Enhance the Effectiveness of Education. First, the school set up the overall operation of the curriculum. The subjects and courses acquired by college students can play a role in the maintenance of life and the promotion of life. Life education course for college students in a good education in the ecosystem can complement each other by many related courses, and many courses of interaction, mutual complementarity and common development. Give full play to the agglomeration effect of the subject, enhance the overall vitality and competitiveness of the curriculum, to create a supportive environment for the implementation of life education courses for college students. Secondly, the family to participate in curriculum co interaction mechanism. Life education is different from other disciplines, it is a kind of comprehensive educational activities, is a systematic social engineering. It calls for family participation in life education, focusing on family and school positive interaction, close cooperation, which is very important for the life education curriculum for college students. The university can through interviews with parents and other forms, with parents actively establish contact, build a bridge of communication between the students in the family environment and school curriculum, can make the daily life practical courses and students to establish direct association. Finally, the external guarantee mechanism. The state should formulate special laws and regulations about life education, the school administrators, educators, social workers, parents and other types of social behavior constraints, providing effective guarantee for the growth of life. Governments at all levels and the administrative departments of education should set up a special life education institutions, as an organizational guarantee for the implementation of life education, the establishment of a complete 
social network of life education. Give full play to the television, radio, newspapers, magazines and other social media will play a role, ways and means to guide and regulate the role of the college students' life education as an indispensable; from the community to the memorial hall, from technology to art, from law to morality are good, good service.

\section{Conclusion}

Life is the most precious, and its concept is complex and rich. In order to better understand life, understand life, care for life, sublimation of life, we call for the arrival of life education. Life education curriculum is an important medium and approach to the implementation of life education, which not only provides the basis for content, but also promotes the continuous promotion of life education. This paper analyses problems of life education curriculum in Colleges and universities, and expounds the realistic basis of curriculum implementation and its importance, and the construction of university life education curriculum, the implementation process of the life education curriculum for the detailed explanation, has certain practical significance.

\section{Acknowledgements}

This Study is a research project of Higher Education in Jilin Province in 2015. The title of this project is the Design and Practice of the Curriculum System of Life Education in Colleges and Universities. The project approval number is JGJ2015.

\section{References}

[1] C.Q Li, Chunhua Chen. Ecological ethics [M]. Beijing: Science Press, 1994. (In Chinese)

[2] J.L Liu. Life education [M]. Beijing: China Social Sciences Press,2004. (In Chinese)

[3] L.F Li. Research on the necessity and new way of life education for contemporary college students $[\mathrm{J}]$. Journal of Southwest Agricultural University (SOCIAL SCIENCE EDITION),2011,(5). (In Chinese)

[4] Bourne. D. Towards a theory of development education[N].The Development Education Journal,2003,(1).

[5] Gregor Ziemer. Education for Death: The Making of the Nani[M].New York: A Division of Farrar. Straus and Giroux.1972.

[6] Jeffreys, M.V.C. Education: It is Nature Purpose[M].Australia: Prentice Hall of Australia Pty, 1990

[7] The McGraw-Hill.Health\&Wellness:Grade7[M].New York :Macmillan / McGraw- Hill.2005.

[8] Joe Downer Hua Teshi.Life Education [M].Oxford University Press, 1987.

[9] Lynn Margulis Dorion Sagan. What Is Life[M].California: University of California Press.2000

[10]E White. Life, death. And the pursuit of apoptosis [M].Genes Dev,1996. 